\title{
Implementasi Socket Programming Sebagai Media Sinkronisasi Database Terdistribusi dengan Teknik Multi Master Replication
}

\author{
Made Pradnyana Ambara', Pande Ketut Widiartana², Yohanes Priyo Atmojo ${ }^{3}$ \\ Institut Teknologi dan Bisnis STIKOM Bali \\ e-mail: ${ }^{1}$ pradnyana_ambara@yahoo.com, ${ }^{2}$ widigent.coder@gmail.com, ${ }^{3}$ yohanes@ $@$ stikom-bali.ac.id \\ Diajukan: 30 Januari 2020; Direvisi: 4 Juni 2020; Diterima: 17 Juni 2020
}

\begin{abstract}
Abstrak
Dalam sebuah database terdistribusi, database disimpan tersebar di banyak lokasi yang terpisah namun saling berhubungan satu sama lain. Sinkronisasi data pada database terdistribusi yang heterogenous, dengan sumber data yang secara geografis terletak tersebar di beberapa lokasi yang sangat jauh adalah salah satu masalah dalam penerapannya. Sinkronisasi database yang dilakukan dengan cara export file SQL secara manual di sistem sumber, kemudian dikirimkan melalui email untuk di import di sistem tujuan sangat tidak efektif di mana sangat sering terjadi kesalahan pada sisi user dalam export import file-nya. Penelitian ini bertujuan memberikan solusi atas permasalahan tersebut dengan menerapkan teknik pemrograman socket untuk membangun aplikasi yang berfungsi sebagai media sinkronisasi otomatis pada datatabase terdistribusi. Hasil dari penelitian ini adalah sebuah middleware yang dapat menyinkronkan data pada database terdistribusi menggunakan teknik multi master replication. Teknik ini dapat meningkatkan availability dari database sehingga ketika terjadi kerusakan atau kegagalan pada satu lokasi fisik maka tidak menyebabkan kegagalan keseluruhan sistem pada database. Middleware ini akan membaca setiap perubahan pada database kemudian mengirimkannya melalui komunikasi socket ke aplikasi server. Aplikasi server kemudian akan mem-broadcast perubahan tersebut ke semua client yang terhubung. Metode penelitian yang digunakan adalah metode waterfall model meliputi pengumpulan data, analisa dan desain sistem serta pembuatan dan uji coba.
\end{abstract}

Kata kunci: Sinkronisasi database terdistribusi, Socket programming, Multi master replication.

Abstract

In a distributed database, databases are stored scattered in many separate but interconnected locations. Synchronizing data in a heterogeneous distributed database, with data sources that are geographically located scattered in several locations very far away is one of the problems in its application. Database synchronization which is done by manually exporting SQL files in the source system, then sent by email to be imported in the destination system is very ineffective where very often there are errors on the user side in the export import file. This study aims to provide a solution to these problems by applying socket programming techniques to build applications that function as automatic synchronization media in a distributed database. The result of this research is a middleware that can synchronize data in a distributed database using multi master replication techniques. This technique can increase the availability of a database so that when there is damage or failure at one physical location, it does not cause an overall system failure in the database. This middleware will read every change in the database then send it via socket communication to the server application. The server application will then broadcast the changes to all connected clients. The research method used is the waterfall model method including data collection, analysis and system design as well as manufacturing and testing.

Keywords: Distributed database synchronization, Socket programming, Multimaster replication.

\section{Pendahuluan}

Dalam perkembangannya, semakin besar sebuah perusahaan, maka semakin besar dan semakin kompleks juga data yang diproses sehingga diperlukan sebuah teknologi untuk menangani masalah ini. Pendistribusian database merupakan salah satu langkah yang sangat tepat apabila jumlah client yang ditangani oleh suatu aplikasi semakin bertambah banyak. Masalah yang dihadapi oleh perusahaan yang 
menerapkan sistem database terdistribusi yang heterogenous, dengan sumber data yang secara geografis terletak tersebar di beberapa lokasi dengan jarak yang sangat jauh adalah bagaimana menyinkronkan data tersebut secara otomatis dan realtime. Sinkronisasi antar database yang dilakukan dengan cara export file Structured Query Language (SQL) secara manual di sistem sumber, yang kemudian dikirimkan melalui email untuk di-import di sistem tujuan sangat tidak efektif di mana sangat sering terjadi kesalahan pada sisi user dalam export ataupun import file-nya. Kesalahan yang paling sering terjadi adalah lupa mengexport data transaksi dari satu tempat untuk di-import di tempat lain atau lupa meng-import data transaksi di satu tempat dari tempat lain, yang menyebabkan data menjadi tidak valid sehingga sangat diperlukan tools berupa middleware yang dapat melakukan sinkronisasi secara otomatis.

Dalam penelitian yang berjudul "Implementasi Heterogenous Distributed Database System Oracle Xe 10g dan MySQL" menjelaskan tentang implementasi heterogenous distributed database dengan replikasi horizontal menghasilkan sistem informasi yang dapat berjalan dengan baik walaupun salah satu atau lebih server mengalami masalah seperti down server atau kerusakan pada basis data. Data yang sedang diproses juga tidak akan hilang, karena sudah dilakukan replikasi data secara horizontal ke Database Management System (DBMS) server yang sedang aktif. Namun demikian masih diperlukan sinkronisasi manual untuk melakukan update data sehingga data pada server yang sedang melakukan sinkronisasi memiliki data yang sama dengan server lainnya[1]. Pada penelitian yang berjudul "Implementasi Socket TCP/IP untuk Mengirim dan Memasukkan File Text ke Dalam Database" menghasilkan simpulan bahwa menggunakan socket, transfer data bisa ditransmisikan antara program aplikasi dan mengirimkan file ataupun input file dan TCP/IP layak sebagai sarana pengiriman data ke aplikasi lain [2]. Penelitian lain dengan judul "Program Socket untuk Mengirim File dengan Visual Basic pada Sistem Operasi Windows" menghasilkan kesimpulan bahwa aplikasi pada jaringan komputer, transaksinya didasarkan pada konsep client-server dengan menggunakan protokol transport untuk saling berinteraksi [3].

Penulis melakukan penelitian ini dengan tujuan untuk memberikan solusi terhadap masalah bagaimana cara untuk sinkronisasi data pada database terdistribusi yang heterogenous secara otomatis dan realtime, dengan mengimplementasikan socket programming sebagai media sinkronisasi database terdistribusi dengan teknik multimaster replication dengan membangun middleware application. Penulis memilih metode ini dengan mengembangkan penelitian oleh [1], di mana dengan mengirimkan tiap perubahan data pada database melalui komunikasi socket tidak diperlukan lagi sinkronisasi secara manual dan dengan didukung penelitian yang dilakukan oleh [2] bahwa komunikasi socket TCP/IP layak sebagai sarana pengiriman data. Dengan teknik ini setiap perubahan data pada semua database client akan dapat direplika secara multimaster, otomatis, dan realtime.

\section{Metode Penelitian}

\subsection{Socket Programming, Client, dan Server}

Socket adalah sebuah cara untuk berkomunikasi dengan program atau node lain menggunakan file descriptor [4]. Unix dengan slogannya "everything is a file" merupakan tempat di mana socket diciptakan, membuat komunikasi dengan program atau node menjadi semudah membaca dan menulis file descriptor. Socket client adalah sebuah penghubung antara dua host, yang dapat dibangun dengan tujuh dasar operasi yang meliputi menghubungkan mesin atau perangkat, kemudian mengirim dan menerima data, menutup koneksi, menyiapkan port, listening data yang masuk, serta menerima koneksi dari mesin berdasarkan sebuah port [4]. Socket Server adalah socket yang akan digunakan untuk menangani koneksi dari Client [4]. Socket server digunakan pada aplikasi server dengan mengimplementasikan Class Server Socket yang menyediakan constructor untuk memilih IP mana yang akan digunakan, karena server dapat menggunakan IP Address lebih dari satu.

\subsection{Database Terdistribusi dan Database Trigger}

Basis data (database) adalah representasi kumpulan fakta yang saling berhubungan disimpan secara bersama sedemikian rupa dan tanpa pengulangan (redundancy) yang tidak perlu, untuk memenuhi berbagai kebutuhan [5]. Dengan bantuan perangkat lunak seperti DBMS, data yang tersimpan dalam database dapat dikelola dengan mudah dan cepat untuk tujuan penyediaan informasi yang berkualitas. Basis data terdistribusi/Distributed Database $(D D B)$ adalah suatu kumpulan berbagai basis data yang secara logika saling berhubungan satu dengan lainnya, yang terdistribusi dalam suatu network komputer [2]. Di dalam database terdistribusi file-file database disimpan dalam beberapa database pada komputer-komputer yang secara fisik terpisah satu dengan yang lain. Penyimpanan database dapat dilakukan pada DBMS yang sama (homogenous) ataupun DBMS yang berbeda (heterogenous) namun database haruslah memiliki struktur yang sama. Homogenous Distributed Database adalah basis data yang menggunakan DBMS sama di setiap simpul. Heterogenous Distributed Database yaitu basis data terdistribusi menggunakan DBMS yang 
berbeda pada setiap simpul. Dalam penelitian ini digunakan heterogenous distributed database di mana database pada masing-masing outlet menggunakan DBMS MS SQL Server 2008 Express R2, sedangkan pada database server digunakan MySQL Versi 14.14 Distribusi 5.7.23. Trigger adalah prosedur yang berhubungan dengan table, view, skema, atau database yang dijalankan secara implicit pada saat terjadi sebuah event [6]. Trigger juga dapat diartikan sebagai sebuah store procedure yang berjalan secara otomatis saat terjadi modifikasi pada database, baik modifikasi penambahan data (insert), perubahan data (update), maupun modifikasi penghapusan data (delete).

\subsection{Replikasi}

Replikasi adalah suatu teknik untuk melakukan copy dan pendistribusian data dan objek-objek database dari satu database ke database lain dan melaksanakan sinkronisasi antara database sehingga konsistensi data dapat terjamin [6]. Terdapat dua karakteristik replikasi yaitu:

1. Replikasi Synchronous

Replikasi Synchronous bekerja ketika permintaan update ke master database oleh slave, master mengunci semua database pada tingkat record, dan kemudian meng-update secara bersamaan.

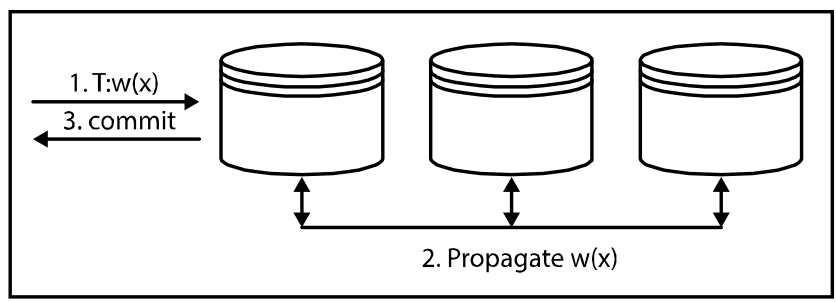

Gambar 1. Replikasi synchronous.

2. Replikasi Asynchronous

Replikasi asynchronous bekerja saat terjadi sebuah transaksi pada sebuah client, Client yang merequest mengeksekusi 1 per 1 hasil respons dari client lainya tadi.

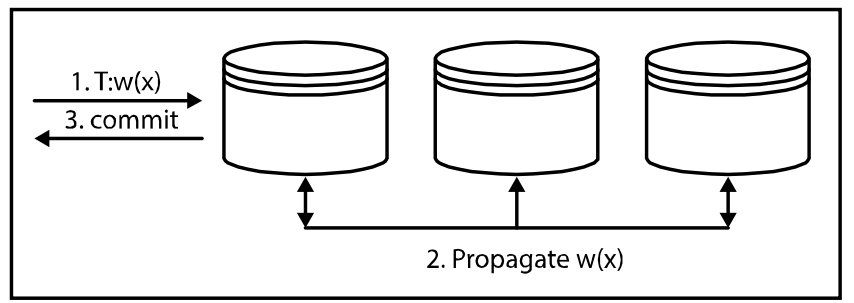

Gambar 2. Replikasi asynchronous.

\subsection{Multi Master Database Replication}

Multi-master database replication memungkinkan seluruh node dalam satu klaster menjadi master database, sehingga perubahan yang terjadi pada satu node akan direplika ke seluruh node yang tergabung dalam klaster tersebut [7]. Teknik ini digunakan dalam penelitian karena dapat meningkatkan availability dari database, di mana backup database terdapat di semua node, sehingga jika terjadi masalah pada salah satu node, maka database tersebut dapat diganti/di-replace menggunakan backup dari database yang lain yang masih dalam satu kesatuan database terdistribusi tersebut. Dengan teknik ini maka ketersediaan backup database menjadi lebih baik.

\subsection{JavaFX}

JavaFX adalah platform klien yang ekspresif untuk menciptakan dan memberikan pengalaman internet yang mendalam di berbagai layar. Aplikasi JavaFX ditulis menggunakan bahasa deklaratif yang diketik secara statis yang disebut JavaFX Script yang membuatnya mudah diprogram dalam konteks visual, memungkinkan pengembang untuk membuat GUI yang sangat ekspresif dan intuitif dengan cepat dan mudah [8]. 


\subsection{Alur Kerja Penelitian}

Ada beberapa model alur kerja software yang umum digunakan, salah satunya adalah model waterfall. Model ini melingkupi aktivitas-aktivitas seperti ditunjukkan pada Gambar 3.

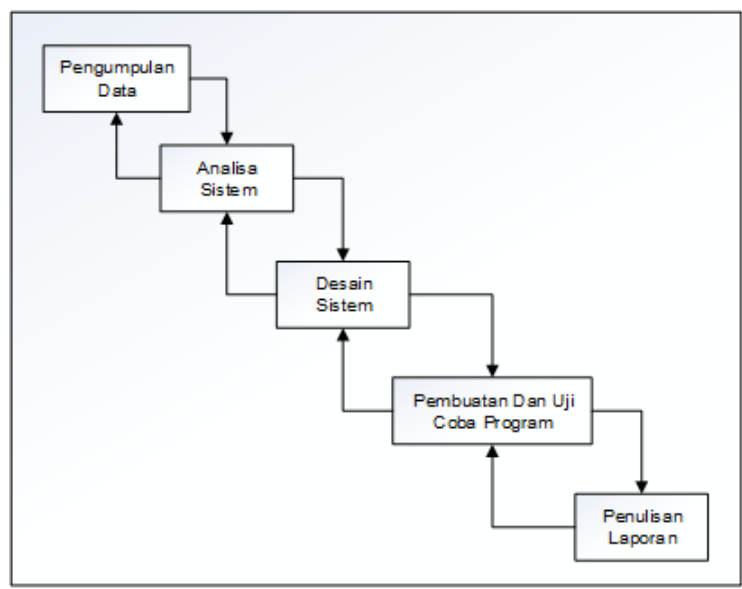

Gambar 3. Waterfall model.

Pengumpulan data merupakan proses yang dilakukan untuk memperoleh informasi yang dibutuhkan dalam rangka mencapai tujuan perekayasaan ini, adapun metode pengumpulan data yang digunakan adalah studi pustaka. Analisis Sistem merupakan tahapan menganalisis permasalahan untuk mengetahui dan menentukan batasan-batasan sistem sehingga dapat menentukan cara yang efektif dalam menyelesaikan permasalahan tersebut dan dapat dirancang sebuah aplikasi. Desain sistem pada perekayasaan ini menggunakan UML (Unified Modeling Language) yang akan menjelaskan mengenai interaksi pengguna dengan sistem. Integrated Development Environment (IDE) yang digunakan dalam penelitian ini adalah Netbean 8 dengan bahasa pemrograman Java dengan JavaFX API dan FXML. Kemudian database yang digunakan adalah MS SQL Server dan MySQL server. Pengujian sistem dilakukan untuk mengidentifikasikan dan mengevaluasi permasalahan-permasalahan yang muncul pada saat pengoperasian aplikasi tersebut. Metode pengujian yang digunakan adalah black box testing.

\subsection{Use Case Diagram}

Dalam use case terdapat aktivitas apa saja yang dapat dilakukan oleh admin pada aplikasi server. Pada aplikasi server terdapat lima aktivitas yang dilakukan oleh admin antara lain start server, stop server, quit server, dan show about. Dalam show about user dapat melihat informasi aplikasi server. Gambar 4 menunjukkan use case diagram pada server.

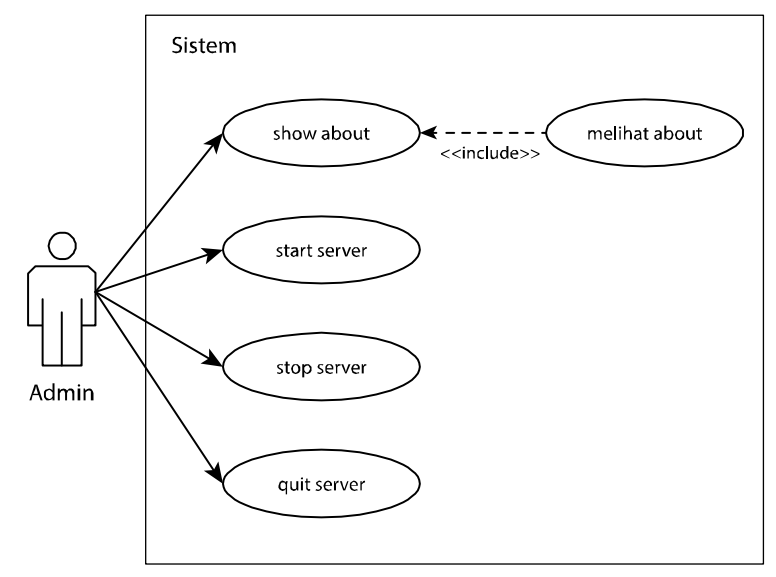

Gambar 4. Use case diagram server.

Pada client terdapat enam belas aktivitas yang dilakukan oleh dua aktor dengan pembagian sebagai berikut. Admin dapat melakukan login sebagai admin kemudian dilanjutkan dengan aktivitas setup client, add outlet, ignore outlet, dan logout. Pada aktivitas setup client, admin dapat melakukan aktivitas setup 
company info, setup server connection, setup database connection, dan test connection. Aktivitas yang dikakukan oleh client juga dapat dilakukan oleh admin. Use case diagram pada client ditunjukkan pada Gambar 5.

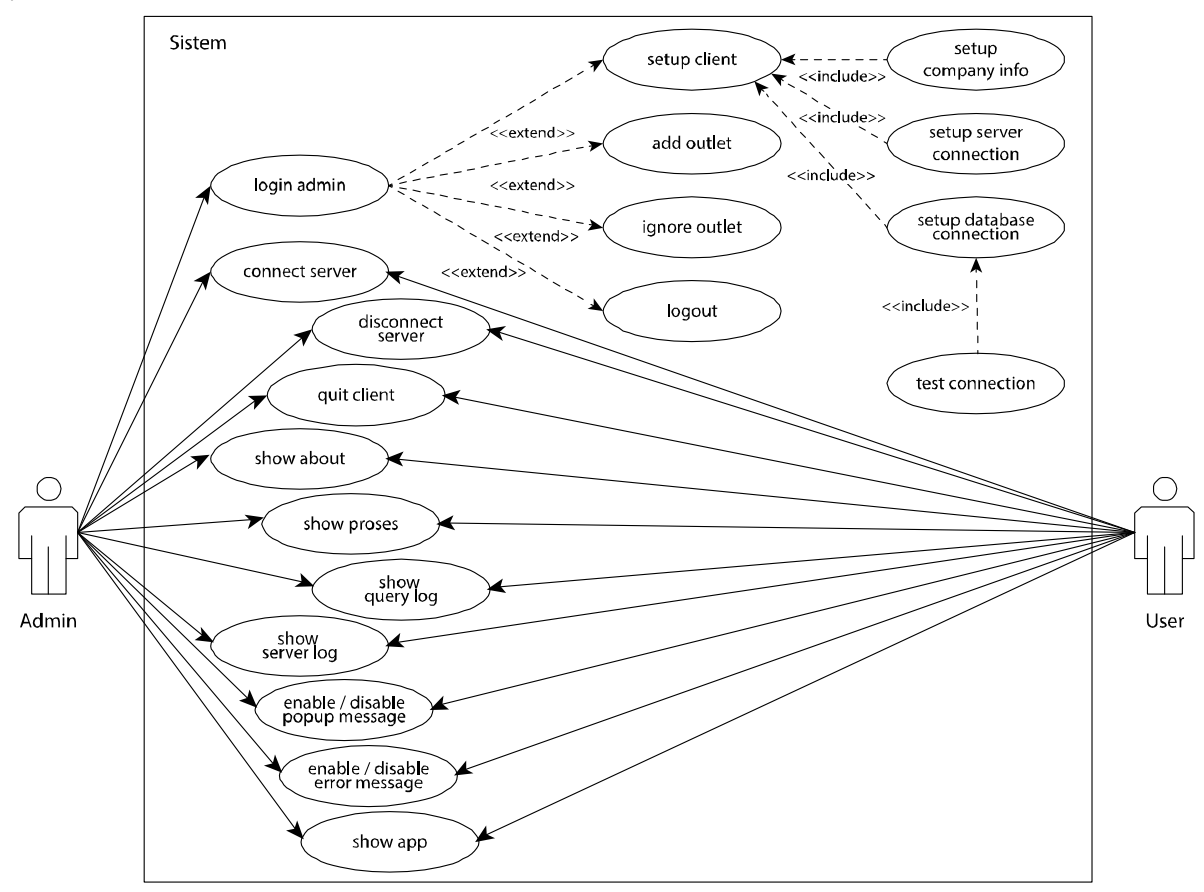

Gambar 5. Use case diagram client.

\subsection{Flowchart Start Server pada Aplikasi Server}

Sebelum aplikasi client dapat terkoneksi ke aplikasi server, aplikasi server harus membuka sebuah Socket server dengan mengimplementasikan Class Server Socket dengan menggunakan port dan IP yang telah disimpan dalam setup server. Flowchart start server pada aplikasi server dapat dilihat pada Gambar 6.

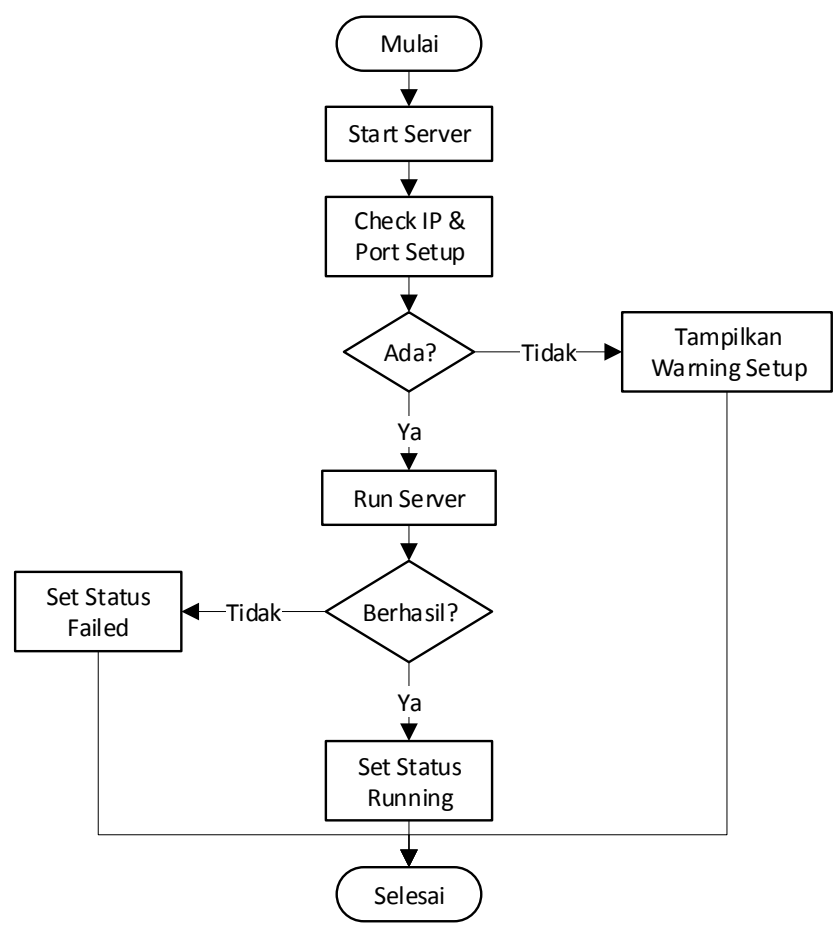

Gambar 6. Flowchart start server pada aplikasi server. 


\subsection{Flowchart Koneksi ke Server pada Aplikasi Client}

Jika aplikasi server telah siap untuk menerima koneksi maka aplikasi client siap untuk dikoneksikan ke aplikasi server. Flowchart koneksi client ke server dapat dilihat pada Gambar 7.

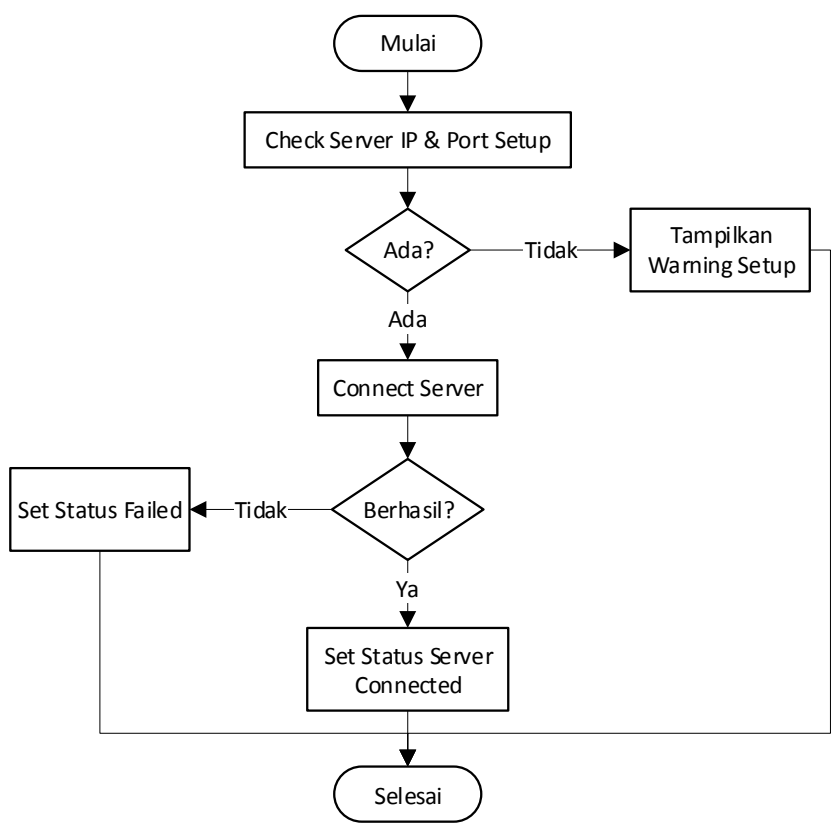

Gambar 7. Flowchart koneksi ke server pada aplikasi client.

\subsection{Flowchart Pengecekan Trigger pada Aplikasi Client}

Pada saat aplikasi client start, aplikasi akan memeriksa apakah trigger sudah ada pada database client yang akan disinkronkan. Jika trigger tidak ada, maka trigger akan ditambahkan ke database. Trigger ini berfungsi membuat querystring dari setiap perubahan pada database, baik karena operasi insert, update, maupun delete seperti terlihat pada Gambar 8.

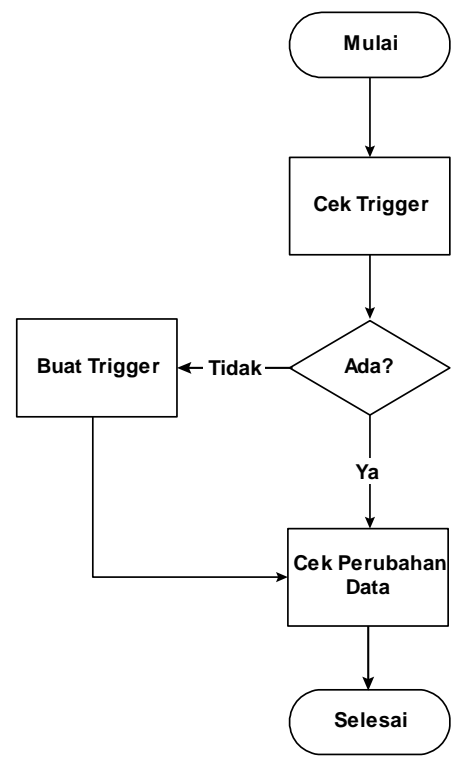

Gambar 8. Flowchart trigger check

\subsection{Flowchart Pengiriman Data pada Aplikasi Client}

Pada saat aplikasi client berjalan, aplikasi akan mengecek apakah ada perubahan pada database dengan membaca tabel CloudQuery yang diisi data oleh trigger. Jika terjadi perubahan data pada database, maka tabel CloudQuery akan terisi record dengan ExportFlag status 0. Jika pengiriman data ini ke server berhasil, maka aplikasi akan mengubah status dari record tersebut seperti Gambar 9. 


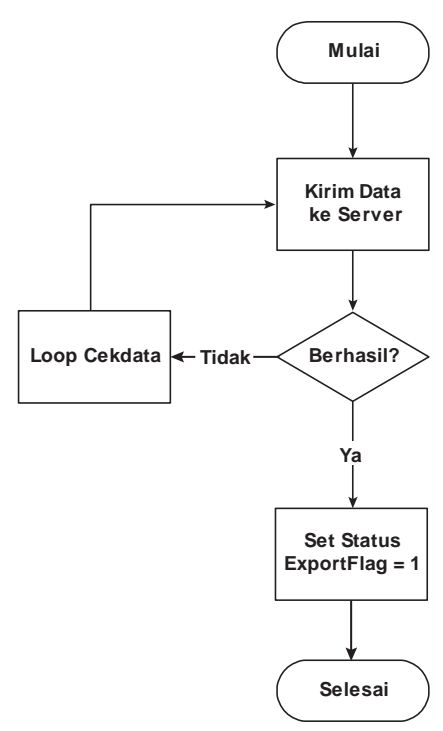

Gambar 9. Flowchart pengiriman data ke server.

\subsection{Flowchart Penerimaan Data pada Aplikasi Client}

Aplikasi client saat menerima data dari server akan meng-execute data tersebut ke database. Jika data yang berupa SQL tersebut berhasil di-execute, maka aplikasi akan mengirimkan message ke server bahwa data berhasil di-execute.

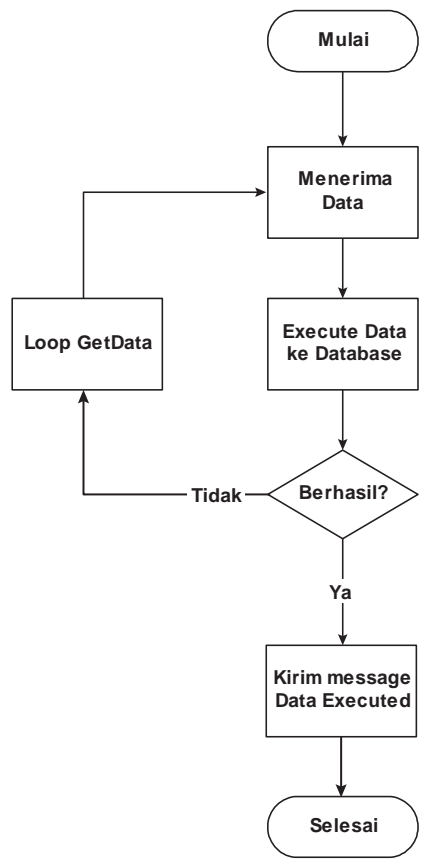

Gambar 10. Flowchart penerimaan data pada client.

\subsection{Flowchart Penerimaan Data pada Aplikasi Server}

Pada aplikasi server, saat menerima data dari client, server akan menyimpan data tersebut ke dalam database. Data disimpan dengan status 0 sebanyak client yang ada kecuali client pengirim data. Jika penyimpanan data berhasil, aplikasi akan mengirimkan message ke client pengirim bahwa data sudah berhasil dieksekusi. Data ini kemudian akan dibaca untuk dikirimkan ke setiap client kecuali client yang mengirim data tersebut. 


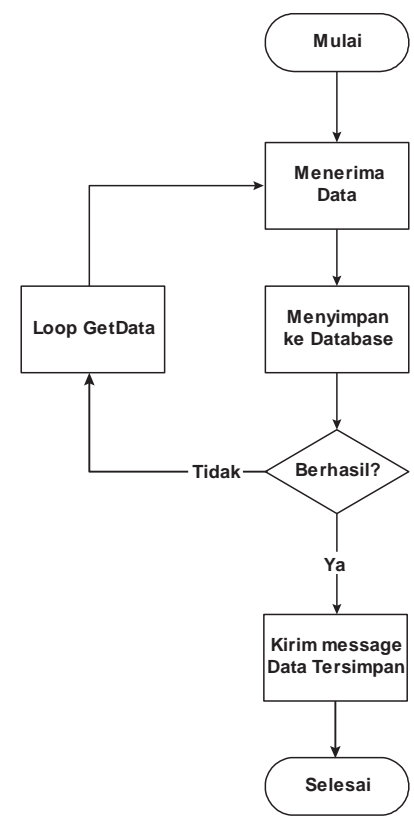

Gambar 11. Flowchart penerimaan data pada server.

\subsection{Flowchart Broadcast Data pada Aplikasi Server}

Aplikasi server secara terus menerus mengecek data pada antrean di database server. Jika terdapat data dengan status 0 , maka data tersebut akan di-broadcast ke semua client yang sedang online. Jika broadcast berhasil, maka status data tersebut di ubah menjadi 1 untuk masing-masing client yang berhasil meng-execute SQL data tersebut ke database-nya.

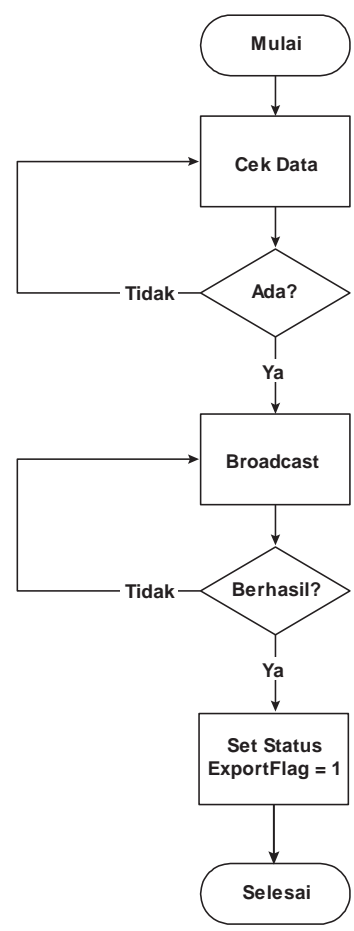

Gambar 12. Flowchart broadcast data pada server.

\section{Hasil dan Pembahasan}

\subsection{Gambaran Umum Sistem}

Aplikasi middleware yang dihasilkan dalam penelitian ini berfungsi sebagai media sinkronisasi database terdistribusi dengan teknik multi master replication. Aplikasi ini berfungsi sebagai middleware 
yang akan memeriksa apakah terjadi perubahan pada database yang diidentifikasi dari perubahan tabel CloudQuery yang berisikan querystring dari setiap transaksi yang dilakukan oleh user pada aplikasi yang terkoneksi ke database tersebut dan kemudian mengirim querystring tersebut ke aplikasi server untuk kemudian di-broadcast ke semua cabang. Gambaran umum sistem ditunjukkan pada Gambar 13.

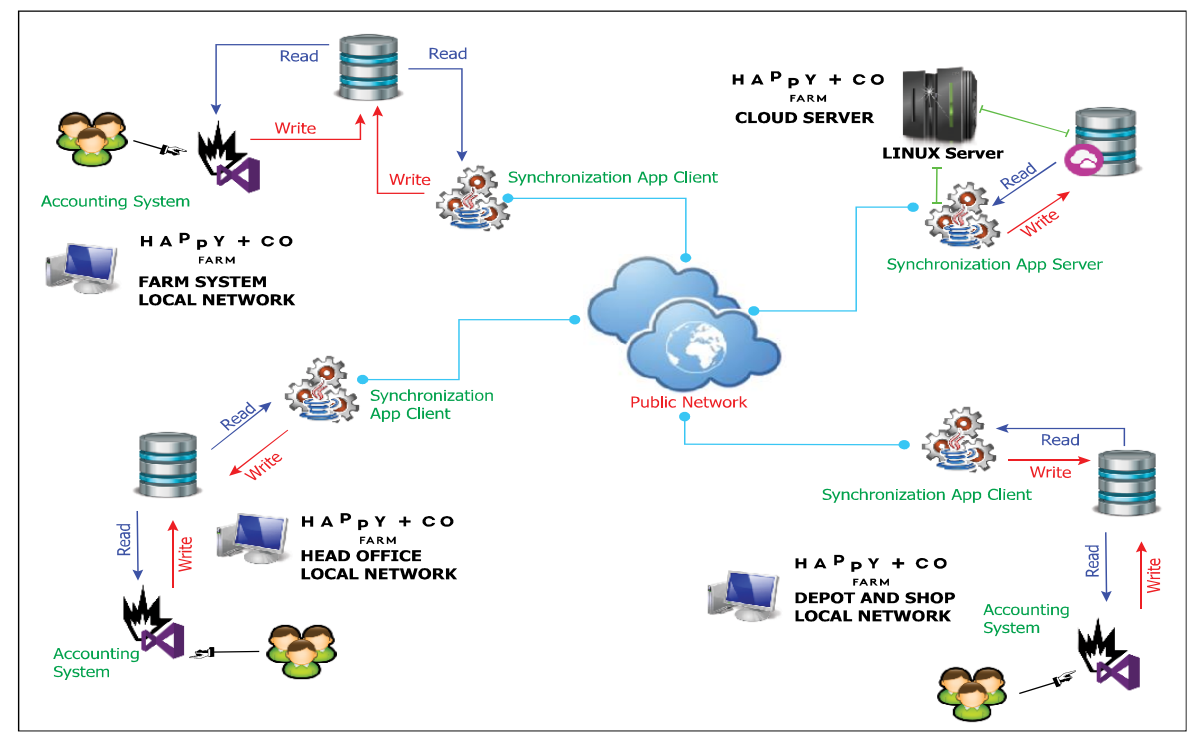

Gambar 13. Gambaran umum sistem.

\subsection{Implementasi Sistem}

Aplikasi ditulis dalam bahasa Java dengan design antar mukanya menggunakan JavaFX. Aplikasi terdiri dari aplikasi server dan aplikasi client. Aplikasi server di-install di komputer server yang dapat dikelola oleh admin. Aplikasi ini berfungsi untuk menerima koneksi dari semua client dan menyimpan data yang masuk ke database dengan status ExportFlag $=0$. Aplikasi server secara terus menerus mengecek data yang status ExportFlag-nya $=0$ untuk kemudian di-broadcast ke semua client kecuali client pengirim data. Jika server menerima message bahwa data yang dikirimkan ke client telah berhasil di-execute oleh client, maka aplikasi server akan mengubah status ExportFlag dari data tersebut menjadi 1. Tampilan aplikasi server dapat dilihat pada Gambar 14.

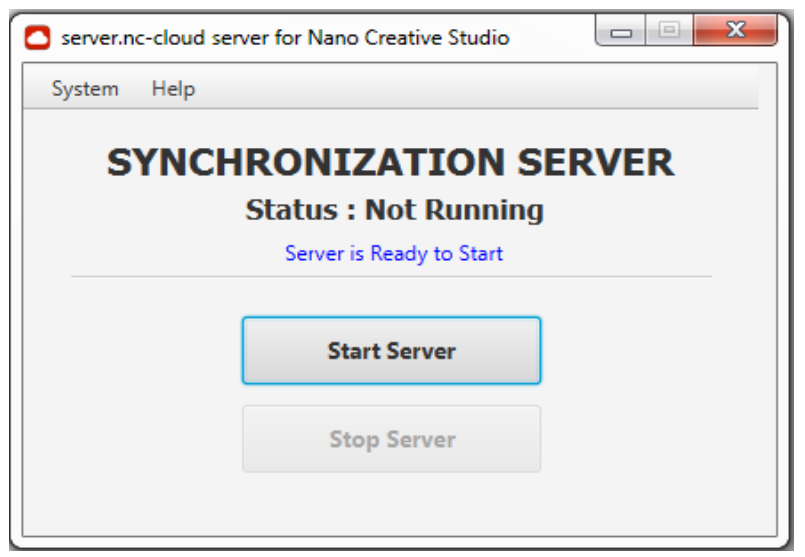

Gambar 14. Tampilan aplikasi server.

Aplikasi client di-install di masing-masing computer outlet. Aplikasi ini berfungsi untuk mengecek perubahan yang terjadi pada database aplikasi dengan bantuan trigger. Saat aplikasi dijalankan, aplikasi client akan mencoba untuk terkoneksi ke server. Jika gagal, aplikasi client akan melakukan mencoba secara otomatis sebanyak tiga kali berselang 10 detik. Jika koneksi ke server tetap gagal, maka ditampilkan pesan untuk menyarankan koneksi secara manual melalui menu connect server seperti terlihat pada Gambar 15. 


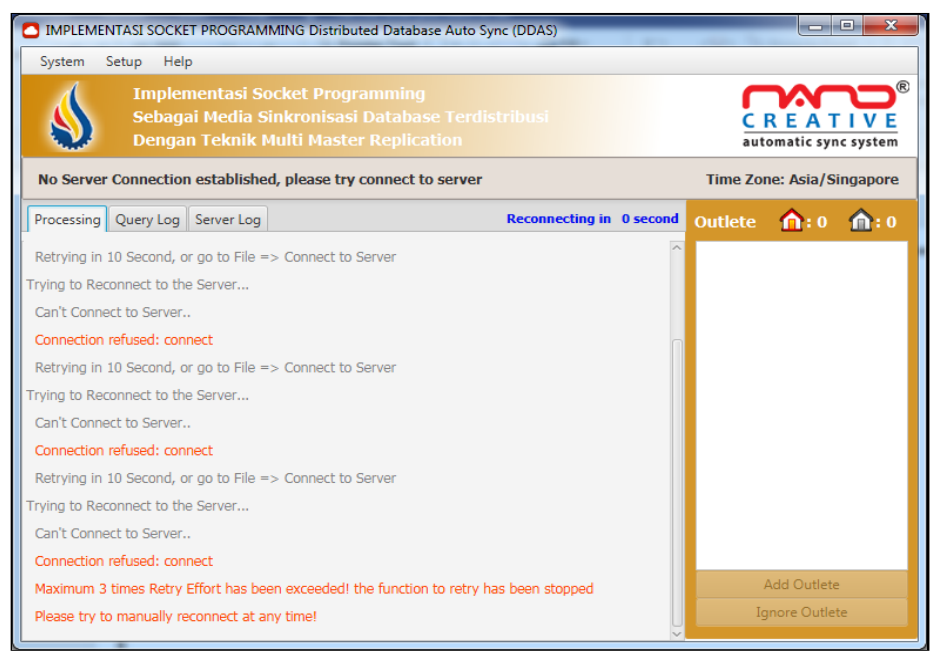

Gambar 15. Tampilan aplikasi client gagal terkoneksi ke server.

Kegagalan koneksi ke server dapat terjadi karena aplikasi server belum di-start sehingga tidak ada socket server yang terbuka atau dapat juga terjadi karena koneksi jaringan terputus atau down.

Jika aplikasi server telah terkoneksi ke server seperti terlihat pada Gambar 16, dan terdapat antrean data di server maka aplikasi client akan menerima semua data yang masih mengantre di database server. Kemudian client akan mengecek apakah terjadi perubahan data pada tabel CloudQuery. Jika terdapat perubahan data maka aplikasi akan mengirimkan data tersebut ke server dan mengubah export flag menjadi 1 jika berhasil. Tampilan aplikasi client pada saat sinkronisasi data dapat dilihat pada Gambar 17.

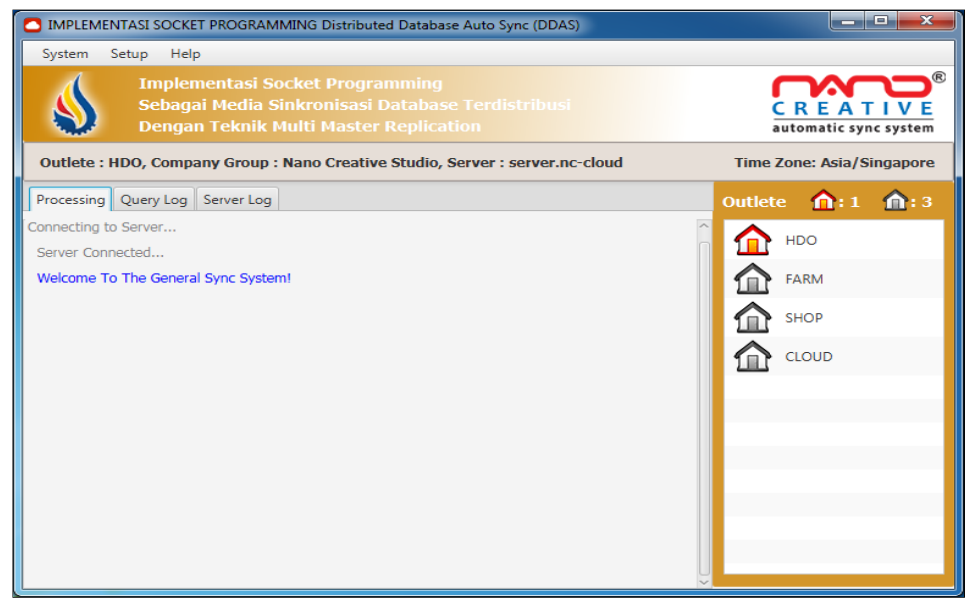

Gambar 16. Tampilan aplikasi client setelah berhasil terhubung dengan server. 


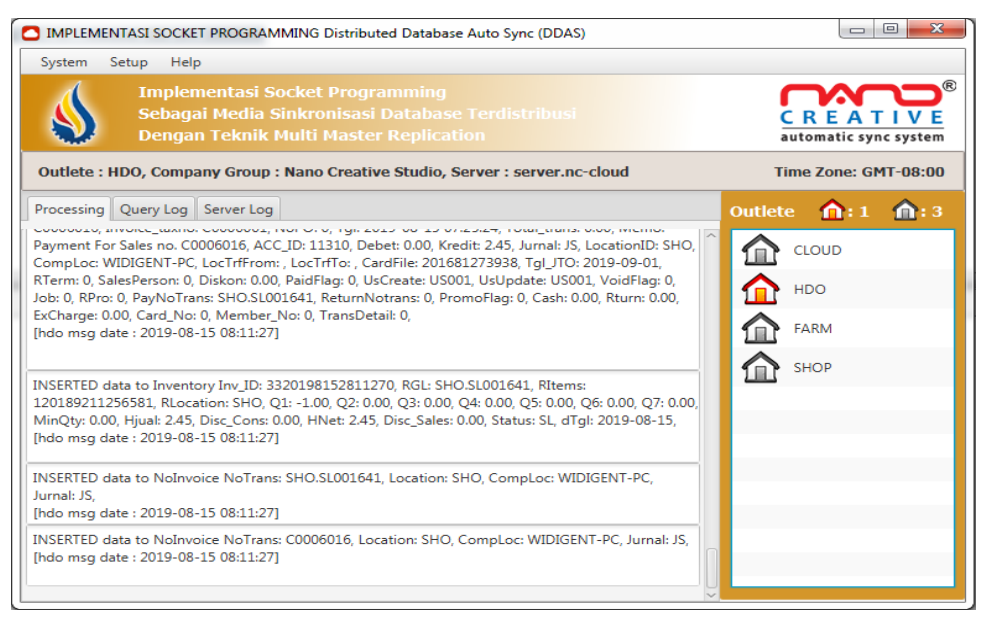

Gambar 17. Tampilan aplikasi client saat sinkronisasi data.

Hasil eksekusi query yang dikirimkan oleh server dapat dilihat pada tab query log pada aplikasi client. Terdapat kolom tanggal, message, status, dan sender. Kolom tanggal menampilkan data tanggal dan waktu query dieksekusi, kolom message menampilkan transaksi yang dieksekusi dan detail datanya. Kolom status menampilkan status dari query tersebut telah dieksekusi dan kolom sender menampilkan data outlet yang mengirim query tersebut. Log query ini dapat dilihat pada Gambar 18.

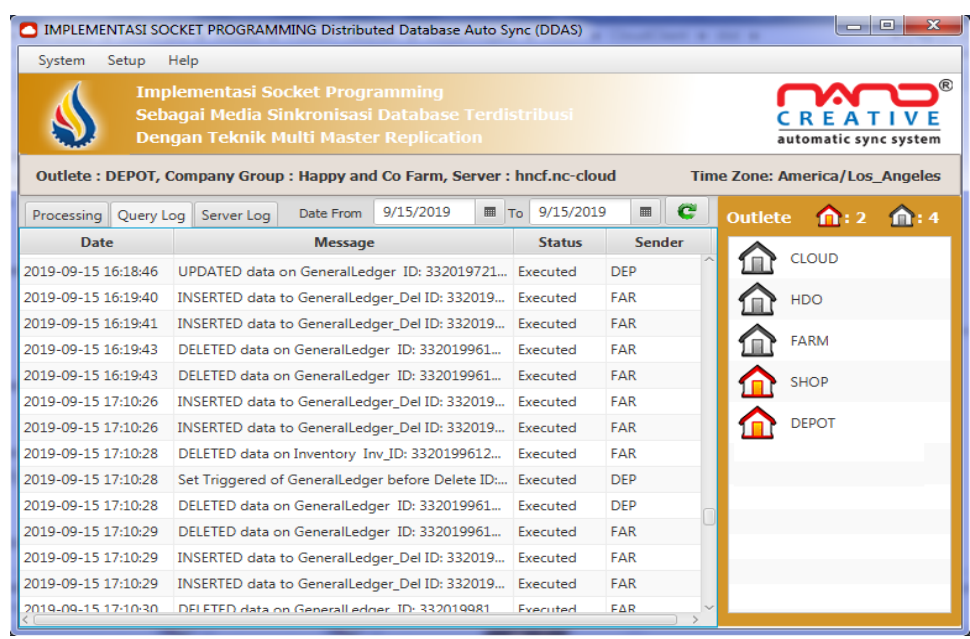

Gambar 18. Tampilan aplikasi client saat sinkronisasi data.

\subsection{Hasil Pengujian}

Pengujian yang dilakukan meliputi respons system saat client mencoba terhubung dengan server, respons system jika client telah terkoneksi dengan server, dan respons system saat terjadi perubahan pada database client. Pengujian dilakukan oleh 3 orang tester yang memiliki kemampuan dibidang pemrograman database yang memfokuskan pada fungsional kinerja sistem. Hasil pengujian dengan metode black box testing, bahwa sistem yang dirancang $100 \%$ sesuai dengan apa yang diharapkan. Skenario pengujian dapat dilihat pada Tabel 1 dan hasil kuesioner check list pengujian pada Tabel 2.

Tabel 1. Skenario pengujian black box testing

\begin{tabular}{clllc}
\hline No & Skenario Pengujian & \multicolumn{1}{c}{ Masukan } & \multicolumn{1}{c}{ Hasil yang diharapkan } & Hasil Pengujian \\
\hline 1 & $\begin{array}{l}\text { Mengetahui respons } \\
\text { sistem jika } \text { client } \text { mencoba } \\
\text { terhubung dengan server }\end{array}$ & $\begin{array}{l}\text { User } \text { dan } \text { admin } \\
\text { memilih menu } \\
\text { connect to server }\end{array}$ & $\begin{array}{l}\text { Sistem menampilkan informasi server } \\
\text { terhubung dan menampilkan daftar } \text { outlet } \\
\text { sesuai pada Gambar 16 }\end{array}$ & $\begin{array}{c}\text { V Sesuai } \\
\text { Tidak Sesuai }\end{array}$ \\
\hline 2 & $\begin{array}{l}\text { Dst...5 skenario pengujian fungsional sistem. Jumlah skenario pengujian ini disesuaikan pada ruang lingkup sistem yang } \\
\text { dirancang. }\end{array}$ & & \\
\hline
\end{tabular}


Tabel 2. Hasil kuesioner pengujian black box testing.

\begin{tabular}{|c|c|c|c|c|c|c|c|c|c|c|c|c|}
\hline \multirow{2}{*}{ No } & \multirow{2}{*}{ Programmer } & \multicolumn{2}{|c|}{ SP1 } & \multicolumn{2}{|c|}{ SP2 } & \multicolumn{2}{|c|}{ SP3 } & \multicolumn{2}{|c|}{ SP4 } & \multicolumn{2}{|c|}{ SP5 } & \multirow{2}{*}{ Hasil } \\
\hline & & $\mathbf{S}$ & TS & $\mathbf{S}$ & TS & $\mathbf{S}$ & TS & $\mathbf{S}$ & TS & $\mathbf{S}$ & TS & \\
\hline 1 & P1 & 1 & 0 & 1 & 0 & 1 & 0 & 1 & 0 & 1 & 0 & $\mathrm{~S}=5, \mathrm{TS}=0$ \\
\hline 2 & $\mathrm{P} 2$ & 1 & 0 & 1 & 0 & 1 & 0 & 1 & 0 & 1 & 0 & $\mathrm{~S}=5, \mathrm{TS}=0$ \\
\hline 3 & P3 & 1 & 0 & 1 & 0 & 1 & 0 & 1 & 0 & 1 & 0 & $\mathrm{~S}=5, \mathrm{TS}=0$ \\
\hline \multicolumn{12}{|c|}{ HP1 $=($ Jumlah S / Jumlah SP $) \times 100 \%=(5 / 5) \times 100 \%$} & $100 \%$ \\
\hline \multicolumn{12}{|c|}{ HP2 $=($ Jumlah S / Jumlah SP $) \times 100 \%=(5 / 5) \times 100 \%$} & $100 \%$ \\
\hline \multicolumn{12}{|c|}{ HP3 $=($ Jumlah S / Jumlah SP $) \times 100 \%=(5 / 5) \times 100 \%$} & $100 \%$ \\
\hline \multicolumn{12}{|c|}{ Hasil Pengujian } & $100 \%$ Sesuai \\
\hline
\end{tabular}

Keterangan :

$\begin{array}{lll}- & \text { SP } & \text { : Skenario Pengujian } \\ \text { - } & \text { S/TS } & \text { : Sesuai / Tidak Sesuai } \\ \text { - } & \text { P } & \text { : Programmer } \\ \text { - } & \text { HP } & \text { : Hasil Programmer }\end{array}$

\section{Kesimpulan}

Dari hasil penelitian, perancangan, dan implementasi yang telah dilakukan, dapat ditarik beberapa kesimpulan bahwa dihasilkan sebuah aplikasi middleware yang bekerja dengan baik sesuai fungsinya sebagai media sinkronisasi database yang dapat melakukan sinkronisasi data pada database terdistribusi yang heterogenous melalui komunikasi socket. Sinkronisasi ini berjalan secara otomatis setelah aplikasi server dan aplikasi client terhubung dan dapat menyinkronkan data antara DBMS MsSQL Server dan DBMS MySQL Server.

Penulis menyadari banyak kekurangan dalam penelitian ini sehingga perlu dilakukan pengembangan dan penyempurnaan lebih lanjut. Oleh karena itu penulis ingin memberikan saran yaitu sistem ini perlu dikembangkan dengan menambahkan fitur enkripsi pada data yang terkirim melalui komunikasi jaringan untuk tujuan keamanan data.

\section{Daftar Pustaka}

[1] V. A. Abrar and M. D. R. Wahyudi, "Implementasi Heterogenous Distributed Database System Oracle Xe 10g dan MySQL Rekam Medis Poliklinik UIN Sunan Kalijaga,” Citec J., vol. 4, no. 1, 2017.

[2] I. F. Anshori, "Implementasi Socket Tcp/Ip Untuk Mengirim Dan Memasukan File Text Kedalam Database," J. Responsive, vol. 1, no. 1, 2019.

[3] H. Listiyono, "Program Socket Untuk Mengirim file Dengan Visual Basic Pada Sistem Operasi WIndows," J. Responsive, vol. 1, no. 1, 2019.

[4] K. Agus, "Mengenal Socket” in Pemrograman Jaringan Dengan Java. Yogyakarta, Indonesia, 2011.

[5] S. Arifin, B. Antonius, and A. Abdul, "Pembangunan Sistem Informasi Presensi Perkuliahan Menggunakan Basis Data Terdistribusi Dengan Metode Replikasi-Asynchronus," Itsmart, vol. 4, no. $2,2015$.

[6] D. A. Hidayat, "'Rancang Bangun Aplikasi Point of Sale (POS) Berbasis Web Dengan Pemanfaatan Trigger Pada Distribution Store CV.NMRQ,"” J. Sist. dan Teknol. Inf., vol. 2, no. 2, 2014.

[7] M. Data, G. Ramadhan, and K. Amron, ", 'Analisis Availabilitas dan Reliabbilitas Multi-Master Database Server dengan State Snapshot transfers (SST) Jenis Rsync pada MariaDB Galera Cluster,"” J. Teknol. Inf. dan Ilmu Komput., vol. 4, no. 1, 2017.

[8] P. Lawrence and M. Praveen, "“'Introduction to JavaFX“" in Beginning JavaFX,” Springer Sci. Media, 2010. 